\title{
Pengaruh Kerapatan Tanaman terhadap Pertumbuhan dan Hasil Benih Kentang (Solanum tuberosum L.) Generasi Satu $\left(G_{1}\right)$ Varietas Granola
}

\author{
DOI: $10.18196 /$ pt.2017.067.15-22
}

\author{
Deden Fatchullah \\ Balai Penelitian Tanaman Sayuran, \\ Jl. Tangkuban Perahu 517, Kotak Pos 8413 Lembang 40391, Jawa Barat, Indonesia, Telp. 022 2786245, Fax. 022 - 2789951, 2787676, \\ e-mail: Fatchullah1960@gmail.com
}

\begin{abstract}
ABSTRAK
Percobaan dilakukan di Kebun Percobaan Balai Penelitian Tanaman Sayuran (Balitsa), Desa Cikole, Kecamatan Lembang, Kabupaten Bandung Barat dari bulan September sampai bulan Desember 2015. Tempat penelitian berada pada ketinggian 1.250 meter dpl dengan jenis tanah Andosol dan tipe iklim B (Basah). Tujuan percobaan ini adalah untuk mendapatkan kerapatan tanaman yang memberikan pengaruh terbaik terhadap pertumbuhan dan hasil benih generasi satu (G1) varietas Granola. Metode percobaan yang digunakan adalah metode eksperimen menggunakan Rancangan Acak Kelompok (RAK) faktor tunggal dengan 6 ulangan. Terdapat 4 Perlakuan jarak tanam yaitu $A_{1}(5 \mathrm{~cm} \times 5 \mathrm{~cm}), A_{2}(6 \mathrm{~cm} \times 6 \mathrm{~cm}), A_{3}(7 \mathrm{~cm} \times 7 \mathrm{~cm})$ dan $A_{4}(8 \mathrm{~cm} \times 8 \mathrm{~cm})$. Hasil percobaan menunjukkan terdapat pengaruh yang nyata jarak tanam terhadap tinggi tanaman umur 21 hst, kanopi tanaman umur 21 hst, dan persentase tumbuh umur 63 hst. Tanaman tertinggi terdapat pada perlakuan A1 jarak tanam (5 cm x $5 \mathrm{~cm}$ ) umur 21 hst yaitu 15,11 cm, kanopi tanaman tertinggi terdapat pada perlakuan A1 jarak tanam $(5 \mathrm{~cm} \times 5 \mathrm{~cm})$ umur 21 hst yaitu 10,40 cm dan persentase tumbuh tanaman tertinggi terdapat pada perlakuan A4 jarak tanam (8 cm x $8 \mathrm{~cm})$ yaitu 27,34\%.

Kata kunci: Solanum tuberosum, Kerapatan tanaman, Benih generasi satu, Varietas granola
\end{abstract}

\begin{abstract}
The experiment was conducted in Experimental Research Station of Indonesian Institute for Vegetable Research (IIVR) at Cikole, Lembang city, West Bandung in September to December 2015. The research area was located in $1250 \mathrm{~m}$ above sea level with the type of soil is Andosol, and type of climate is $B$ (Wet). The objective of this experiment was to find out the effect of plant spacing on the growth and the quality of potato seed (Solanum tuberosum L. var granola) of the first generation (G1). The experiment was arranged in a randomized block design (RBD) with a single factor. The treatment was 4 types of plant spacing: $A 1(5 \mathrm{~cm} \times 5 \mathrm{~cm}), A 2(6 \mathrm{~cm} \times 6 \mathrm{~cm}), A 3(7 \mathrm{~cm} \times 7 \mathrm{~cm})$ and $A 4(8 \mathrm{~cm} \times 8 \mathrm{~cm})$. The result showed that the plant spacing was significantly affecting on plant height and plant canopy at 21 days after planting (DAP), and percentage of germination at 63 DAP. It was determined that $A 1$ plant spacing $(5 \mathrm{~cm} \times 5 \mathrm{~cm})$ provide the highest plant $(15.11 \mathrm{~cm})$ and highest plant canopy $(10.40 \mathrm{~cm})$ at 21 DAP, and A4 plant spacing $(8 \mathrm{~cm} \times 8 \mathrm{~cm})$ present the highest of a percentage of germination (27,34\%).

Keywords: Solanum tuberosum, Plants density, Seed of first generation, Granola variety
\end{abstract}

\section{PENDAHULUAN}

Kentang adalah tanaman pangan utama keempat dunia setelah gandum, padi, dan jagung. Kentang merupakan salah satu jenis tanaman hortikultura yang dikonsumsi umbinya, atau dikenal sebagai sayuran umbi yang banyak mengandung karbohidrat dan sangat bermanfaat bagi tubuh manusia. Nilai gizi pada kentang tergolong tinggi terutama kandungan karbohidrat, sehingga kentang dikenal sebagai bahan pangan yang dapat mensubtitusi sumber karbohidrat lain. Namun, produksi kentang di berbagai wilayah di Indonesia kurang produktif (Rubatzky dan Yamaguchi, 1998).

Proses produksi tanaman kentang sebenarnya tidak memerlukan waktu yang panjang. Kentang dapat dipanen dalam waktu tiga sampai empat bulan tergantung varietas yang digunakan. Pemilihan varietas yang sesuai dan pengelolaan budidaya kentang yang baik akan sangat berpengaruh pada peningkatan hasil tanaman. Hasil utama kentang adalah umbi, bahan pangan yang kaya akan vitamin dan mineral (Samadi, 2007). 
Data konsumsi kentang di Indonesia dari tahun 2007-2011 tercantum pada Tabel 1 .

Tabel 1. Data Konsumsi Rumah Tangga Komoditas Kentang 2007 - 2011

\begin{tabular}{cccccc}
\hline Uraian & \multicolumn{5}{c}{ Tahun } \\
\cline { 2 - 6 } & 2007 & 2008 & 2009 & 2010 & 2011 \\
\hline $\begin{array}{c}\text { Konsumsi kentang seminggu } \\
\text { (kg/kap/minggu) } \\
\begin{array}{c}\text { Konsumsi kentang setahun } \\
\text { (kg/kap/tahun) }\end{array}\end{array}$ & 0,040 & 0,039 & 0,033 & 0,035 & 0,030 \\
\hline
\end{tabular}

Produktivitas tanaman kentang di Indonesia 13,38 ton/ha, namun dari tahun ketahun luas areal, hasil produksi, dan produktivitas kentang mengalami fluktuasi. Produktivitas kentang di Indonesia relatif masih rendah disebabkan penggunaan mutu bibit yang mempunyai kualitas rendah, pengetahuan yang kurang tentang budidaya, penanaman secara terus menerus dan permodalan petani yang terbatas (Sunarjono, 2007). Produksi, luas panen, dan produktivitas kentang di Indonesia dari tahun 2010-2014 dapat dilihat pada Tabel 2.

Tabel 2. Produksi, Luas Panen dan Produktivitas Tanaman Kentang

\begin{tabular}{cccc}
\hline Tahun & Produksi (ton) & Luas Panen (ha) & Produktivitas (ton/ha) \\
\hline 2010 & 1.060 .805 & 66.531 & 15,94 \\
2011 & 955.488 & 59.882 & 15,96 \\
2012 & 1.094 .232 & 65.989 & 16,58 \\
2013 & $1.124,282$ & 70.187 & 16,02 \\
2014 & 1.316 .015 & 76.090 & 17,30 \\
\hline
\end{tabular}

Sumber: Badan Pusat Statistik dan Dirjen Hortikultura Produktivitas Kentang (2015).

Salah satu usaha untuk meningkatkan produksi kentang adalah dengan meningkatkan teknik budidaya di antaranya menggunakan umbi yang bermutu tinggi yang meliputi mutu genetik, mutu fisiologis dan mutu fisik. Mutu genetik dicirikan oleh kemurnian benih sehingga benih tanpa ada varietas lain di dalamnya, mutu fisiologis umbi kentang dicirikan dengan reproduksi umbi, pembentukan dan perkembangan biji, daya perkecambahan viabilitas, daya simpan yang tinggi, vigor dan kemunduran benih. Sedangkan, mutu fisik mencakup tingkat keseragaman yang tinggi baik bentuk, warna, ukuran dan berat jumlah atau volume (Sadjad, 1993).

Bibit adalah bakal terjadinya suatu tanaman, oleh karena itu sangat menentukan hasil yang akan dicapai, umbi yang mempunyai mutu baik dapat membantu meningkatkan produktivitas kentang (Gunadi, 1993). Bibit kentang dapat diperbanyak secara vegetatif melalui umbinya serta dapat digunakan pula bagian - bagian lainnya seperti stek pucuk, stek tunas, dan stek batang (Rukmana, 1997). Penggunaan varietas unggul sangat berperan dalam peningkatan dan produktivitas kentang, akan tetapi keunggulan suatu varietas dibatasi oleh berbagai faktor, termasuk penurunan ketahanan terhadap hama dan penyakit tertentu setelah dikembangkan dalam periode tertentu.

Penggunaan kerapatan tanaman pada dasarnya untuk memberikan ruang serta pertumbuhan tanaman yang baik tanpa mengalami persaingan antara sesama tanaman. Menurut Abidin (1984), jarak tanam untuk kerapatan tanam bisa mempengaruhi lingkungan tumbuh dan hasil tanaman, semakin rapat jarak tanam semakin tinggi populasi tanaman sehingga kompetisi antar tanaman untuk menyerap unsur hara dari tanah akan meningkat. Penggunaan kerapatan tanam dalam pembibitan kentang secara vegetatif, yakni $5 \mathrm{~cm} \times 5 \mathrm{~cm}, 6 \mathrm{~cm} \times 6 \mathrm{~cm}, 7 \mathrm{~cm}$ x $7 \mathrm{~cm}$, dan $8 \mathrm{~cm}$ x $8 \mathrm{~cm}$, menunjukan bahwa semakin rapat jarak tanamnya makin kecil umbi yang dihasilkan (Sunarjono, 2008).

Dari segi agronomis yang mempengaruhi produksi umbi asal stek adalah kerapatan tanaman karena variabel ini erat kaitannya dengan 
pengaturan jarak tanam (Karjadi, 1996). Menurut Smith (1968) dalam Karjadi (1996) ternyata jarak tanam yang sempit akan menghasilkan presentase ukuran umbi kecil paling besar. Menurut Abidin et al. (1984), jika jarak tanam melampaui batas minimum kerapatan tanaman, maka hasil umbi yang dipanen tidak akan meningkat secara menguntungkan. Penggunaan jarak tanam dapat berpengaruh terhadap naungan daun karena adanya perombakan struktur daun, penambahan tinggi tanaman, penurunan jumlah anakan dan jumlah cabang (Ansori dan Haryadi 1973, Fatullah dan Asandhi 1992).

Jarak tanam untuk kentang konsumen akan berbeda dengan jarak tanam untuk kentang bibit (umbi mini). Hasil penelitian Karjadi (1990), khusus varietas Granola, kerapatan yang digunakan antara $70 \mathrm{~cm}$ x $15 \mathrm{~cm}$ sampai dengan $70 \mathrm{~cm}$ x $30 \mathrm{~cm}$. Pada kerapatan ini persentase ukuran umbi mininya lebih besar. Untuk ukuran umbi mini $<10 \mathrm{~g}$ terbanyak dihasilkan untuk ukuran $70 \mathrm{~cm} \times 15 \mathrm{~cm}$ (ukuran plot $2 \mathrm{~m} \times 2 \mathrm{~m}$, umbi mini jumlah 40,69). Menurut Abdullah (1994), telah dilakukan percobaan jarak tanam untuk produksi umbi mini dengan jarak tanam yang bervariasi $(5 \mathrm{~cm} \times 5 \mathrm{~cm}),(2,5 \mathrm{~cm} \times 5,0 \mathrm{~cm})$, $(1,5 \mathrm{~cm} \times 5,0 \mathrm{~cm})$ dan $(2,5 \mathrm{~cm} \times 2,5 \mathrm{~cm})$ pada kultivar Katahdin. Hasil percobaan tersebut menunjukan bahwa makin tinggi kerapatan tanaman dari semua taraf media yang dicobakan produksi cukup tinggi, namun proporsi umbi bobot 1-10 g (umbi mini) lebih rendah. Persentase umbi mini tertinggi diperoleh pada jarak tanam $(5 \mathrm{~cm} \times 5 \mathrm{~cm})$.

Tujuan penelitian ini adalah untuk mendapatkan kerapatan tanaman yang memberikan pengaruh terbaik terhadap pertumbuhan dan hasil benih generasi satu $\left(G_{1}\right)$ varietas Granola. Hipotesis penelitian ini yaitu kerapatan tanaman berpengaruh nyata terhadap pertumbuhan dan hasil benih generasi satu $\left(G_{1}\right)$ varietas Granola dan terdapat salah satu kerapatan tanaman yang dapat memberikan pengaruh tertinggi terhadap pertumbuhan dan hasil benih generasi satu $\left(G_{1}\right)$ varietas Granola.

\section{BAHAN DAN METODE}

Percobaan dilakukan di Kebun Percobaan Balai Penelitian Tanaman Sayuran (Balitsa) Desa Cikole, Kecamatan Lembang, Kabupaten Bandung Barat. Lokasi Percobaan mempunyai ketinggian 1.250 meter $\mathrm{dpl}$, jenis tanah termasuk jenis tanah Andosol dan tipe iklim B tipe Basah. Percobaan dilaksanakan pada musim kemarau dari bulan September sampai bulan Desember 2015.

Metode penelitian yang digunakan adalah metode eksperimen, menggunakan Rancangan Acak Kelompok (RAK) faktor tunggal dengan 6 ulangan. Terdapat 4 perlakuan jarak tanam yaitu $: A_{1}=(5 \mathrm{~cm} \times 5 \mathrm{~cm}), A_{2}=(6 \mathrm{~cm} \times 6 \mathrm{~cm}), A_{3}=(7$ $\mathrm{cm} \times 7 \mathrm{~cm}), A_{4}=(8 \mathrm{~cm} \times 8 \mathrm{~cm})$.

Analisis ragam (Analysis of variance) dilakukan untuk semua data hasil pengamatan utama, uji F dilakukan pada taraf $5 \%$. Jika hasil uji F dalam analisa ragam menunjukkan berbeda nyata, maka dilanjutkan dengan pengujian beda rata-rata perlakuan tersebut dengan menggunakan uji Duncan atau Duncan Multiple Range Test (DMRT) pada taraf 5 \% (Gomez dan Gomez, 2010).

Pelaksanaan percobaan meliputi kegiatan: persiapan baki plastik tempat penanaman, persiapan stek tunas kentang, persiapan media tanam, pencaplakan, pembibitan stek tunas kentang, pengaturan jarak tanam, penanaman, pemupukan, penyiraman, penyiangan, pengendalian hama dan penyakit serta panen.

Untuk mengetahui pengaruh jarak taman terhadap pertumbuhan tanaman kentang, pen- 
gamatan dilakukan terhadap beberapa varibel tanaman meliputi: tinggi tanaman, kanopi tanaman, persentase tanaman tumbuh, jumlah umbi per tanaman, bobot umbi per tanaman, hasil umbi per petak. Data yang diperoleh kemudian dianalisis statistik.

\section{HASIL DAN PEMBAHASAN}

Tinggi Tanaman

Hasil analisis ragam menunjukkan bahwa jarak tanam berpengaruh nyata terhadap tinggi tanaman pada umur 21 hari setelah tanam (hst), tetapi tidak berpengaruh nyata terhadap tinggi tanaman pada umur 42 hst dan 63 hst. Hasil analisis uji DMRT 5\% menunjukkan bahwa pada pengamatan $21 \mathrm{hst}$, perlakuan $\mathrm{A}_{1}(5 \mathrm{~cm} \times 5$ $\mathrm{cm})$ memberikan tanaman tertinggi yaitu 15,11 $\mathrm{cm}$ dan berbeda nyata terhadap perlakuan $\mathrm{A}_{3}$ dan $A_{4}$, tetapi tidak berbeda nyata dengan perlakuan $A_{2}(6 \mathrm{~cm} \times 6 \mathrm{~cm})$ dengan tinggi $14,48 \mathrm{~cm}$ (Tabel 3). Tanaman kentang dipengaruhi oleh jarak tanam, di mana semakin rapat jarak tanam maka laju pertumbuhan tinggi tanaman semakin tinggi. Selanjutnya menurut Fatullah dan Asandhi (1992), penggunaan jarak tanam dapat berpengaruh terhadap naungan daun, penambahan tinggi tanaman, penurunan jumlah anakan, dan jumlah cabang.

Berbedanya hasil tinggi tanaman pada pengamatan pertama dikarenakan adanya perbedaan dari setiap perlakuan jarak tanam yang dapat berpengaruh pada daya tumbuh tanaman kentang varietas Granola. Sutapradja (2008), menyatakan bahwa walaupun varietas yang digunakan sama tetapi jarak tanam yang digunakan berbeda akan menghasilkan tinggi tanaman yang berbeda pula.

Pada pengamatan 42 hst menunjukkan bahwa tinggi tanaman berbeda tidak nyata antar perlakuan jarak tanam (Tabel 3). Hal ini dikarenakan oleh faktor lingkungan salah satunya adalah cahaya matahari. Pada saat tanaman berumur 30 sampai 42 hst mulai memasuki musim penghujan, sehingga cahaya matahari yang diterima oleh tanaman tidak optimal. Selain itu, tingkat cahaya matahari yang kurang dikarenakan musim penghujan tersebut, dapat menjadi penyebab tanaman mengalami etiolasi. Diketahui sinar matahari berguna bagi fotosintesis pada tanaman tetapi efek lain dari sinar matahari yaitu menekan pertumbuhan sel tanaman yang menyebabkan tanaman yang diterpa matahari akan lebih pendek daripada tanaman yang tumbuh di tempat gelap (Salisburry, 1995 dalam Adinan, 2015).

Tabel 3. Pengaruh Kerapatan Tanaman terhadap Pertumbuhan dan Hasil Benih Kentang (Solanum tuberosum L.) Generasi Satu (G1) Varietas Granola pada Komponen Tinggi Tanaman

\begin{tabular}{ccccc}
\hline \multirow{2}{*}{ Kode } & \multirow{2}{*}{$\begin{array}{c}\text { Perlakuan } \\
\text { Jarak Tanam (cm) }\end{array}$} & $21 \mathrm{hst}$ & $42 \mathrm{hst}$ & $63 \mathrm{hst}$ \\
\cline { 3 - 5 } A1 & $5 \mathrm{~cm} \times 5 \mathrm{~cm}$ & $15,11 \mathrm{a}$ & $44,70 \mathrm{a}$ & $59,59 \mathrm{a}$ \\
$\mathrm{A} 2$ & $6 \mathrm{~cm} \times 6 \mathrm{~cm}$ & $14,48 \mathrm{a}$ & $45,36 \mathrm{a}$ & $59,81 \mathrm{a}$ \\
A3 & $7 \mathrm{~cm} \times 7 \mathrm{~cm}$ & $11,67 \mathrm{~b}$ & $40,50 \mathrm{a}$ & $62,58 \mathrm{a}$ \\
A4 & $8 \mathrm{~cm} \times 8 \mathrm{~cm}$ & $10,43 \mathrm{~b}$ & $38,95 \mathrm{a}$ & $64,87 \mathrm{a}$ \\
& $\mathrm{CV} \mathrm{( \% )}$ & 9,40 & 11,26 & 9,19 \\
\hline
\end{tabular}

Keterangan: Nilai rata-rata yang ditandai dengan huruf yang sama pada setiap kolom yang sama menunjukkan tidak berbeda nyata pada DMRT 5\%.

Etiolasi yang terjadi pada tanaman kentang umur 42 hst dan 63 hst ini disebabkan oleh intensitas cahaya matahari yang rendah karena musim penghujan. Oleh sebab itu, pertumbuhan seluruh tanaman percobaan menjadi seragam dan tidak memperlihatkan hasil yang signifikan. Pada pengamatan 63 hst, antar perlakuan juga menunjukkan tidak berbeda nyata. Hal ini dikarenakan pada umur 63 hst tanaman, tanaman sudah memasuki fase generatif sehingga fase pertumbuhan tinggi tanaman sudah terhenti dan tanaman berfokus pada pembentukan umbi. Samadi (2007), menyatakan bahwa tanaman 
pembentuk umbi, pada fase generatif terjadi hambatan pertumbuhan batang. Tanaman kentang varietas Granola merupakan jenis kentang determinate yang berarti tanaman ini akan berhenti pertumbuhannya setelah memasuki fase generatif (Setiawan, 2011).

\section{Kanopi Tanaman}

Hasil analisis ragam menunjukkan jarak tanam berpengaruh nyata terhadap komponen kanopi tanaman pada umur 21 hst, tetapi tidak berpengaruh nyata pada komponen kanopi tanaman pada umur 42 hst dan 63 hst.

Tabel 4. Pengaruh Kerapatan Tanaman terhadap Pertumbuhan dan Hasil Benih Kentang (Solanum tuberosum L.) Generasi Satu (G1) Varietas Granola pada Komponen Rata-rata Kanopi Tanaman (cm)

\begin{tabular}{ccccc}
\hline \multirow{2}{*}{ Kode } & \multirow{2}{*}{$\begin{array}{c}\text { Perlakuan } \\
\text { Jarak Tanam (cm) }\end{array}$} & \multicolumn{3}{c}{ Rata-rata Kanopi Tanaman $(\mathrm{cm})$} \\
\cline { 3 - 5 } & & $21 \mathrm{hst}$ & $42 \mathrm{hst}$ & $63 \mathrm{hst}$ \\
\hline A1 & $5 \mathrm{~cm} \times 5 \mathrm{~cm}$ & $10,40 \mathrm{a}$ & $18,41 \mathrm{a}$ & $23,52 \mathrm{a}$ \\
A2 & $6 \mathrm{~cm} \times 6 \mathrm{~cm}$ & $10,08 \mathrm{a}$ & $19,58 \mathrm{a}$ & $24,15 \mathrm{a}$ \\
A3 & $7 \mathrm{~cm} \times 7 \mathrm{~cm}$ & $8,78 \mathrm{~b}$ & $18,24 \mathrm{a}$ & $23,60 \mathrm{a}$ \\
A4 & $8 \mathrm{~cm} \times 8 \mathrm{~cm}$ & $7,80 \mathrm{~b}$ & $19,24 \mathrm{a}$ & $26,92 \mathrm{a}$ \\
& $\mathrm{CV}(\%)$ & 9,00 & 9,69 & 8,85 \\
\hline
\end{tabular}

Keterangan: Nilai rata-rata yang ditandai dengan huruf yang sama pada setiap kolom yang sama menunjukkan tidak berbeda nyata pada DMRT 5\%.

Uji DMRT 5\% menunjukkan bahwa pada pengamatan 21 hst, perlakuan $A_{1}(5 \mathrm{~cm}$ x $5 \mathrm{~cm})$ memberikan rata-rata kanopi tanaman tertinggi yaitu $10,40 \mathrm{~cm}$ dan berbeda nyata dengan perlakuan $\mathrm{A}_{3}$ dan $\mathrm{A}_{4}$, tetapi tidak berbeda nyata dengan perlakuan $A_{2}(6 \mathrm{~cm} \times 6 \mathrm{~cm})$ dengan rata -rata kanopi tanaman 10,08 cm (Tabel 4). Hal tersebut disebabkan jarak tanam yang digunakan pada perlakuan $A_{1}(5 \mathrm{~cm} \times 5 \mathrm{~cm})$ dan perlakuan $\mathrm{A}_{2}(6 \mathrm{~cm} \times 6 \mathrm{~cm})$ lebih sempit dibandingkan dengan perlakuan lainnya sehingga daun antara tanaman yang satu dengan yang lainnya lebih cepat menutupi permukaan tanah. Sutapradja (2008), berpendapat bahwa pengaruh kerapatan penanaman adalah pembentukan kanopi daun yang saling bertemu di antara tanaman satu dengan yang lainnya, dengan menutupnya kanopi dedaunan lebih awal dan lebih rapat akan menyebabkan fotosintesis lebih optimal. Selain itu, suhu tanaman lebih sejuk karena terlindungi oleh dedaunannya sendiri. Suhu tanah yang lebih sejuk juga akan mengoptimalkan pertumbuhan umbi yang terbentuk di dalam tanah.

Pada pengamatan 42 hst, kanopi tanaman antar perlakuan menunjukkan berbeda tidak nyata karena tanaman pada umur 30 sampai 42 hst mulai memasuki musim hujan dimana sinar matahari tertutup oleh awan, sehingga mengakibatkan penyerapan sinar matahari oleh daun tidak optimal dan laju fotosintesis terhambat. Hal ini sesuai dengan pendapat Lakitan (2012), yang menyatakan bahwa terhambatnya laju fotosintesis karena kurangnya sinar matahari yang diserap oleh daun.

Pada pengamatan 63 hst, kanopi tanaman antar perlakuan juga menunjukkan berbeda tidak nyata. Hal ini dikarenakan tanaman sudah memasuki fase generatif yang di tandai dengan daun-daun yang sudah mulai menguning dan mulai gugur. Menurut Samadi (2007), tanaman kentang pada fase generatif mulai menunjukkan gejala fisiologis seperti tinggi tanaman terhenti serta daun mulai menguning dan gugur.

\section{Presentase Tanaman Tumbuh}

Hasil analisis ragam pengamatan persentase tanaman tumbuh menunjukkan tidak adanya pengaruh nyata terhadap persentase tanaman tumbuh pada umur 21 hst dan 42 hst, tetapi berpengaruh nyata pada umur 63 hst. Uji DMRT taraf 5\% menunjukkan bahwa nilai CV pada pengamatan 21 hst untuk perlakuan $A_{1}(5 \mathrm{~cm} \mathrm{x}$ $5 \mathrm{~cm}$ ) adalah $17,18 \%$ dan tidak berbeda nyata dengan perlakuan lainnya (Tabel 5). Hal tersebut 
dikarenakan terjadinya perbedaan adaptasi dari setiap perlakuan sehingga menyebabkan daya tumbuh setiap perlakuan berbeda. Johanes dan Dedeh (2014), menyatakan bahwa perkembangan benih saat awal pertunasan sangat dipengaruhi oleh interaksi antara faktor genetik dan faktor lingkungan, pecah tunas sangat ditentukan oleh jenis bibit dan cara budidaya yang digunakan sehingga dapat terjadi perbedaan pada setiap tanaman.

Tabel 5. Pengaruh Kerapatan Tanaman terhadap Pertumbuhan dan Hasil Benih Kentang (Solanum tuberosum L.) Generasi Satu (G1) Varietas Granola pada Komponen Rata-rata Tanaman Tumbuh (\%)

\begin{tabular}{|c|c|c|c|c|}
\hline \multirow{2}{*}{ Kode } & \multirow{2}{*}{$\begin{array}{c}\text { Perlakuan } \\
\text { Jarak Tanam }(\mathrm{cm})\end{array}$} & \multicolumn{3}{|c|}{ Rata-rata Persentase Tumbuh (\%) } \\
\hline & & 21 hst & 42 hst & 63 hst \\
\hline A1 & $5 \mathrm{~cm} \times 5 \mathrm{~cm}$ & $2,50 \mathrm{a}$ & $12,42 \mathrm{a}$ & $18,42 \mathrm{c}$ \\
\hline $\mathrm{A} 2$ & $6 \mathrm{~cm} \times 6 \mathrm{~cm}$ & $2,21 \mathrm{a}$ & $12,95 \mathrm{a}$ & $22,78 \mathrm{~b}$ \\
\hline A3 & $7 \mathrm{~cm} \times 7 \mathrm{~cm}$ & $1,92 \mathrm{a}$ & $10,78 \mathrm{a}$ & $21,89 \mathrm{bc}$ \\
\hline A4 & $8 \mathrm{~cm} \times 8 \mathrm{~cm}$ & $2,23 a$ & $14,31 \mathrm{a}$ & 27,34 a \\
\hline & CV (\%) & 17,18 & 21,09 & 13,54 \\
\hline
\end{tabular}

Keterangan: Nilai rata-rata yang ditandai dengan huruf yang sama pada setiap kolom yang sama menunjukkan tidak berbeda nyata pada DMRT $5 \%$.

Pada pengamatan 42 hst perlakuan $\mathrm{A}_{4}(8 \mathrm{~cm}$ x $8 \mathrm{~cm}$ ) dengan nilai CV 21,09\% tidak berbeda nyata dengan perlakuan lainnya. Hal ini dikarenakan pada umur 42 hst, tanaman kentang mulai memasuki fase generatif. Dimana pada fase ini, pertumbuhan tanaman mulai memfokuskan pada perkembangan bagian tubuh tanamannya, yaitu mulai berkembangnya stolon kentang pada bagian akar (Napitupulu dan Edison, 1997).

Pada pengamatan 63 hst perlakuan $\mathrm{A}_{4}(8$ $\mathrm{cm} \times 8 \mathrm{~cm}$ ) berbeda nyata dengan perlakuan lainnya dengan nilai CV 13,54\%. Hal ini pada perlakuan jarak tanam yang lebar tidak terlalu terjadi kompetisi antar tanaman yang ketat dibandingkan jarak tanam yang rapat. Menurut Jumin dan Napitupulu (1997), agar tidak terjadi persaingan antar tanaman satu dengan lainnya harus diusahakan pengaruh jarak tanam yang sesuai dengan pertumbuhan tanaman.

\section{Jumlah Umbi per Tanaman}

Berdasarkan hasil analisis ragam komponen hasil jumlah umbi per tanaman pada taraf 5\% menunjukkan tidak adanya pengaruh nyata dari setiap perlakuan terhadap jumlah umbi per tanaman.

Uji DMRT taraf 5\% menunjukkan bahwa pada pengamatan jumlah umbi per tanaman perlakuan $\mathrm{A}_{3}(7 \mathrm{~cm} \times 7 \mathrm{~cm})$ memberikan hasil tidak berbeda nyata dengan perlakuan lainnya (Tabel 6).

Tabel 6. Pengaruh Kerapatan Tanaman terhadap Pertumbuhan dan Hasil Benih Kentang (Solanum tuberosum L.) Generasi Satu (G1) Varietas Granola pada Komponen Hasil Jumlah Umbi Per tanaman

\begin{tabular}{ccc}
\hline Kode & $\begin{array}{c}\text { Perlakuan } \\
\text { Jarak Tanam }(\mathrm{cm})\end{array}$ & Jumlah Umbi per Tanaman (knol) \\
\hline A1 & $5 \mathrm{~cm} \times 5 \mathrm{~cm}$ & $21,86 \mathrm{a}$ \\
A2 & $6 \mathrm{~cm} \times 6 \mathrm{~cm}$ & $22,23 \mathrm{a}$ \\
A3 & $7 \mathrm{~cm} \times 7 \mathrm{~cm}$ & $23,75 \mathrm{a}$ \\
A4 & $8 \mathrm{~cm} \times 8 \mathrm{~cm}$ & $20,13 \mathrm{a}$ \\
& $\mathrm{CV} \mathrm{( \% )}$ & 20,52 \\
\hline
\end{tabular}

Keterangan: Nilai rata-rata yang ditandai dengan huruf yang sama pada setiap kolom yang sama menunjukkan tidak berbeda nyata pada DMRT $5 \%$.

\section{Bobot Umbi Per tanaman}

Analisis ragam menunjukkan tidak adanya pengaruh nyata dari setiap perlakuan terhadap hasil bobot umbi per tanaman. Uji DMRT 5\% menunjukkan bahwa pada pengamatan bobot umbi pertanaman perlakuan $A_{2}(6 \mathrm{~cm} \times 6 \mathrm{~cm})$ tidak berbeda nyata dengan perlakuan lainnya (Tabel 7).

Pada Tabel 7, menunjukan tidak ada jarak tanam yang optimum pada semua perlakuan yang diuji terhadap hasil bobot umbi kentang (gr/tanaman). Hal tersebut disebabkan oleh penggunaan jarak tanam yang terlalu sempit sehingga mengakibatkan persaingan unsur hara 
antar tanaman pada setiap setiap perlakuan. Jarak tanam yang sempit akan mengakibatkan terjadinya persaingan air, unsur hara, ruang tumbuh, cahaya matahari dan perkembangan stolon menjadi umbi, sehingga umbi yang dihasilkan pada jarak tanam yang sempit relatif berukuran kecil.

Tabel 7. Pengaruh Kerapatan Tanaman terhadap Pertumbuhan dan Hasil Benih Kentang (Solanum tuberosum L.) Generasi Satu (G1) Varietas Granola pada Komponen Hasil Bobot Umbi Pertanaman

\begin{tabular}{ccc}
\hline Kode & $\begin{array}{c}\text { Perlakuan } \\
\text { Jarak Tanam }(\mathrm{cm})\end{array}$ & Bobot Umbi (gr/tanaman) \\
\hline A1 & $5 \mathrm{~cm} \times 5 \mathrm{~cm}$ & $22,30 \mathrm{a}$ \\
A2 & $6 \mathrm{~cm} \times 6 \mathrm{~cm}$ & $24,48 \mathrm{a}$ \\
A3 & $7 \mathrm{~cm} \times 7 \mathrm{~cm}$ & $22,74 \mathrm{a}$ \\
A4 & $8 \mathrm{~cm} \times 8 \mathrm{~cm}$ & $18,47 \mathrm{a}$ \\
& CV (\%) & 20,55 \\
\hline
\end{tabular}

Keterangan: Nilai rata-rata yang ditandai dengan huruf yang sama pada setiap kolom yang sama menunjukkan tidak berbeda nyata pada DMRT 5\%.

Jarak tanam mempengaruhi tingkat persaingan dalam hal penggunaan air, zat hara dan cahaya matahari yang sangat diperlukan oleh tanaman untuk proses fotosintesis sehingga mempengaruhi hasil umbi. Jika jarak tanam melampaui batas minimum kerapatan tanaman, maka hasil umbi yang dipanen tidak akan meningkat secara menguntungkan (Johanes dan Dedeh, 2014). Jarak tanam yang sempit mengakibatkan tidak adanya ruang untuk perkembangan stolon dan pembesaran umbi. Menurut Fatullah dan Asandhi (1992) jarak tanam berpengaruh terhadap penurunan jumlah anakan tanaman kentang.

\section{Bobot Umbi per petak}

Berdasarkan hasil analisis ragam menunjukan tidak adanya pengaruh nyata dari setiap perlakuan terhadap hasil bobot umbi baki. Uji DMRT 5\% menunjukkan bahwa pada pengamatan bobot umbi per petak perlakuan $\mathrm{A}_{3}(7 \mathrm{~cm}$ x $7 \mathrm{~cm}$ ) tidak berbeda nyata dengan perlakuan lainnya (Tabel 8).
Tabel 8. Pengaruh Kerapatan Tanaman terhadap Pertumbuhan dan Hasil Benih Kentang (Solanum tuberosum L.) Generasi Satu (G1) Varietas Granola pada Komponen Hasil Bobot Umbi per Petak

\begin{tabular}{ccc}
\hline Kode & $\begin{array}{c}\text { Perlakuan } \\
\text { Jarak Tanam (cm) }\end{array}$ & Bobot Umbi (gr/petak) \\
\hline A1 & $5 \mathrm{~cm} \times 5 \mathrm{~cm}$ & $440,67 \mathrm{a}$ \\
A2 & $6 \mathrm{~cm} \times 6 \mathrm{~cm}$ & $486,17 \mathrm{a}$ \\
A3 & $7 \mathrm{~cm} \times 7 \mathrm{~cm}$ & $495,67 \mathrm{a}$ \\
A4 & $8 \mathrm{~cm} \times 8 \mathrm{~cm}$ & $440,33 \mathrm{a}$ \\
& $\mathrm{CV} \mathrm{( \% )}$ & 32,32 \\
\hline
\end{tabular}

Keterangan: Nilai rata-rata yang ditandai dengan huruf yang sama pada setiap kolom yang sama menunjukkan tidak berbeda nyata pada DMRT 5\%.

Penelitian ini menunjukkan bahwa perlakuan jarak tanam tidak berpengaruh nyata terhadap bobot umbi/petak. Namun, jarak tanam $8 \mathrm{~cm}$ x $8 \mathrm{~cm}$ bisa menghemat waktu dan biaya proses penanaman tanaman kentang dan bisa mengurangi kompetisi unsur hara, air dan cahaya matahari, sehingga tanaman tumbuh optimal dan produksinya maksimal.

Pengaturan jarak tanam merupakan salah satu faktor yang dibutuhkan tanaman untuk meningkatkan produksi (Lanna, 2008). Jarak tanam di lapangan akan mempengaruhi produksi tanaman kentang karena adanya persaingan unsur hara, air dan cahaya. Hal ini berpengaruh terhadap kemampuan tanaman untuk menghasilkan jumlah daun yang lebih banyak yang mendukung aktivitas fotosintesis sehingga mampu menghasilkan asimilat yang lebih besar. Besarnya asimilat yang diangkut dan disimpan sebagai cadangan makanan menentukan bobot umbi. Jumlah asimilat yang kecil akan menghasilkan bobot umbi yang lebih kecil dan sebaliknya jika jumlahnya besar akan meningkatkan bobot umbi (Samsul dkk., 2013).

Jarak tanam yang rapat akan mempengaruhi jumlah tanaman per petak sehingga populasi tanaman lebih banyak, sedangkan pada jarak tanam yang renggang populasi tanaman akan semakin sedikit sehingga hal tersebut akan mempengaruhi bobot dan jumlah umbi per 
petak. Penggunaan jarak tanam pada dasarnya untuk memberikan ruang sekitar pertumbuhan tanaman yang baik tanpa mengalami persaingan antar tanaman (Sutapradja, 2008).

\section{SIMPULAN}

Perlakuan jarak tanam berpengaruh nyata terhadap tinggi tanaman umur 21 hst, kanopi tanaman umur 21 hst, dan persentase tumbuh umur 63 hst.

Perlakuan $A_{1}$ (jarak tanam $5 \mathrm{~cm}$ x $5 \mathrm{~cm}$ ) pada umur 21 hst menghasilkan tinggi tanaman tertinggi $(15,11 \mathrm{~cm})$ dan kanopi tanaman terlebar $(10,40 \mathrm{~cm})$, serta berbeda nyata dengan perlakuan $\mathrm{A}_{3}$ dan $\mathrm{A}_{4}$. Selain itu, perlakuan $\mathrm{A}_{4}$ (jarak tanam $8 \mathrm{~cm} \mathrm{x} 8 \mathrm{~cm}$ ) pada umur 63 hst manghasilkan persentase tumbuh tertinggi $(27,34 \%)$ dan berbeda nyata dengan perlakuan lainnya.

\section{DAFTAR PUSTAKA}

Abdullah, A. dan Soedarmanto. 1986. Budidaya Kentang. CV Yasaguna: Jakarta

Abidin, A.A. Asandhi dan Suwahyo. 1984. Pengaruh Kerapatan Tanaman dan Dosis Pupuk Nitrogen terhadap Pertumbuhan dan Hasil Bayam Cabutan. Buletin penelitian Hortikultura XI (1): 1-8.

Adinan, V. 2015. Gejala Etiolasi Pada Tanaman. Blogspot. veliadinan.blogspot.co.id/2015/06/gejala-etiolasi-tanaman. html?m=1. Diakses tanggal 26 April 2016.

Amirullah, J dan Dedeh H. 2014. Keragaman Produksi Jarak Tanam dan Penerapan Teknologi Varietas Kentang (Solanum tuberosum L.) pada Lahan Dataran Tinggi Propinsi Sumatera Selatan. Prosiding Seminar Nasional: Palembang

Ansori, N. dan S.S. Haryadi. 1992. Pengaruh Naungan Terhadap Suatu Varietas Kentang (Solanum Tuberosum L.) dalam Hubungannya denagan Hama Epilachna. Bul. Agronomi. IV (3): 17-27.

Ansori,N. dan S.S. Haryadi, 1973. Pengaruh Naungan Terhadap Suatu Varietas Kentang (Solanum tuberosum L.) dalam Hubungannya dengan Hama Epilachna. Bul. Agronomi. IV (3): 17-18.

Asandhi, 1989. Kentang Balai Penelitian Hortikultura Lembang Jawa Barat.

Badan Pusat Statistik. 2012. Data Konsumsi Rumah Tangga Komoditas Kentang 2007-2011. Jakarta.

Badan Pusat Statistik. 2015. Data Produksi, Luas Panen, dan Produktivitas Tanama Kentang Tahun 2010-2014. Jakarta.

Fatullah. D dan A.A, Asandhi, 1992. Jarak Tanam dan Pemupukan
N Pada Tanaman Kentang Dataran Medium. Bul. Penel, Hort. XXIII (1): 117-123.

Gomez, K.A., and Gomez.A.A. 2010. Prosedur Statistik untuk Penelitian Pertanian. Terjemahan Endang Syamsudin dan Justika S. Baharsjah. Edisi kedua. Penerbit Universitas Indonesia, Jakarta.

Gunadi, N. 1993. Pertumbuhan dan Hasil Kentang dan Hasil Kentang dari Biji dan dari Umbi Asal Progeni yang Sama. Buletin Penelitian Hortikultura. Lembang. XIV (4) : 1-8.

Karjadi, A.K. 1990. Pengaruh Jumlah dan Kerapatan Umbi Mini Kentang Terhadap Produksi Umbi Bibit. Bul. Penel.Hort. XX(1) : 90-97.

Karjadi Kartasih Asih. 1996. Perbaiakan Sistem Pembibitan Kentang Melalui Kultur Jaringan dan Teknik Perbanyakan Cepat. Balai Penelitian Tanaman Sayuran Balai Penelitian Tanaman Sayuran, Badan Penelitian dan Pengembangan Pertanian Bandung.

Lakitan, B. 2012. Fisiologi Tumbuhan. Kanisius. Jakarta.

Napitupulu I,M,Nur dan K. Edison. 1997. Pengaruh Kerapatan Tanam dan Ukuran Umbi Asal Sprout Terhadap Pertumbuhan dan Hasil Kentang (Solanum tuberosum L.) Kultura Fakultas Pertanian USU. XXVII (1) : 34-38.

Pitojo Setiojo, 2004. Benih Kentang. Yogyakarta : Kanisius.

Reni Gustyani, L. 2008. Kajian Tentang Produksi dan Pertumbuhan Tanaman Kentang (Solamun Tuberrosum L.) Varietas Granola Asal Biji Botani Melalui Uji Perkecambahan dan Pengaturan Jarak Tanam. Universitas Sumatra Utara. Medan.

Rubatzky V, Mas Yamaguchi. 1998. Sayuran Dunia. Institut Teknologi Bandung. Bandung.

Rukmana, R. 1997. Kentang Budidaya dan Pasca Panen. Kanisius. Yogyakarta.

Sadjad, S. 1993. Dari Benih Kepada Benih. Gramedia, Jakarta.

Samadi, B. 2007. Kentang dan Analisis Usaha Tani. Yogyakarta: Kanisius.

Samsul Arifin, M. Agung, N. dan Agus S. 2013. Kajian Panjang Tunas dan Bobot Umbi Bibit Terhadap Produksi Tanaman Kentang (Solanum tuberosum L.) Varietas Granola. Universitas Brawijaya : Malang.

Setiawan, R, B. 2011. Pertumbuhan dan Hasil Tanaman Kentang (Solanum tuberosum L.) Varietas Granola yang diberi Porasi M-Bio dan Pupuk PK 15-15-15. Jerami Volume 4 No.3, September - Desember 2011. ISSN 1979-0228.

Sunarjono, Hendro. 2007. Petunjuk Praktis Budidaya Kentang, Cetakan 1. Agromedia Jakarta.

Sunarjono, H. 2008. Berkebun 21 Jenis Tanaman Buah. Penebar Swadaya. Bogor.

Sunarjono, H. 2011. Bertanam 30 Jenis Sayur. Jakarta Penebar Swadaya.

Suryadi dan S. Sahat, 1992. Pengaruh Asal dan Ukuran Umbi Bibit Terhadap Perkembangan Tanaman dan Hasil Kentang (Solanum Tuberosum L.) Kultivar Desine. Penel. Hort XXIV (2) : 21-34.

Sutapradja, H. 2008. Pengaruh Jarak Tanam dan Ukuran Umbi Bibit terhadap Pertumbuhan dan Hasil Kentang Varietas Granola untuk Bibit. Balai Penelitian Tanaman Sayuran: Bandung.

Perkembangan Tanaman Kentang (Solanum Tuberosum L.) Kultipar Desire. Bul. Penel. Hort. XXII (2): 12-18. 